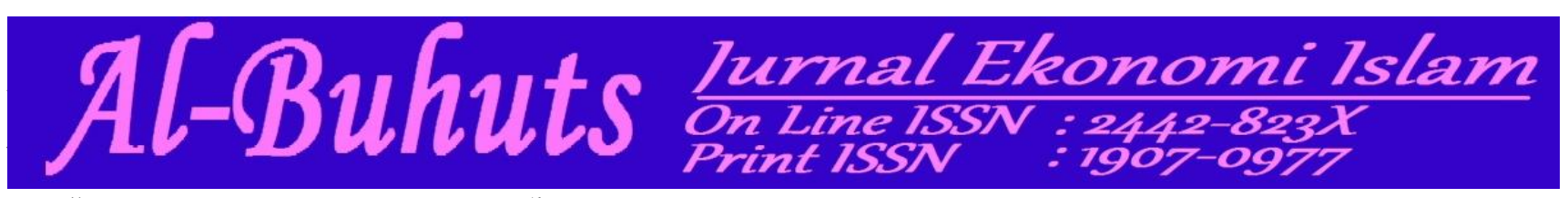

Volume. 13, Nomor 2, Desember 2017

\title{
Analisis Metode Price Earning Ratio Dalam Penetapan Nilai Intrinsik Saham
}

\author{
Fauziah Husain \\ IAIN Sultan Amai Gorontalo \\ Husainfauziah87@gmail.com
}

\begin{abstract}
Abstrak
Nilai intrinsik ini adalah mencari nilai sekarang dari semua aliran kas di masa mendatang, baik yang berasal dari dividen maupun capital gain.Penelitian ini bertujuan untuk menganalisis Metode Price Earning Raio dalam penetapannilai intrinsik saham pada PT Mayora Indah Tbk. Data laporan keuangan yang dikumpulkan dari 2010 - 2016 dan dianalisis dengan metode kuantitatif yang dilakukan dalam bentuk deskriptif yaitu dengan menghitung Price Earning Ratio untuk menetapkan nilai intrinsik saham. Hasil penelitian menunjukan bahwa nilai intrinsik saham PT Mayora Indah Tbk sudah tepat dan telah sama dengan harga pasar sahamnya sebab berada pada posisi Correctly Valued yaitu nilai intrinsik saham sama dengan atau seimbang dengan harga pasar saham. Dimana nilai intrinsiknya sudah merupakan nilai yang wajar atau nilai yang sebenarnya ( yang seharusnya) terjadi di pasar saham.
\end{abstract}

Kata Kunci : Metode Price Earning Ratio, Nilai Intrinsik

\section{Pendahuluan}

Investasi dalam bentuk fisik mengharapkan adanya kenaikan harga aset fisik yang sudah dibeli sehingga menimbulkan keuntungan apabila akan diperdagangkan, sedangkan investasi dalam bentuk aset keuangan yang berupa saham mengharapkan adanya dividen atau capital gainsebagai return atas investasi yang sudah dilakukan. Sebelum melakukan investasi, investor harus melakukan penilaian terhadap saham yang akan dibelinya. Terdapat tiga jenis nilai saham perlu diketahui, yaitu nilai pasar, nilai intrinsik, dan nilai buku. Nilai buku diartikan sebagai nilai yang dihitung oleh emiten berdasarkan catatan pembukuannya, Nilai pasar merupakan harga saham yang ada di pasar dan Nilai intrinsik adalah nilai saham yang menentukan harga wajar suatu saham agar saham tersebut mencerminkan nilai saham yang sebenarnya sehingga tidak terlalu mahal. Perhitungan nilai intrinsik ini adalah mencari nilai sekarang dari semua aliran kas di masa mendatang, baik yang berasal dari dividen maupun capital gain (Sulistyastuti, 2002). Nilai intrinsik memberikanukuran mengenai nilai dasar dari suatu saham dan merupakan standar untukmempertimbangkan apakah saham tersebut dinilai terlalu rendah (undervalued), wajar (fairly priced) atau dinilai terlalu tinggi (overvalued) (Brigham dan Houston, 2006). Seorang investor dalam melakukan analisis nilai

\footnotetext{
${ }^{1}$ Lecturer at Faculty of Economic and Islamic Business, State Islamic Institute of Sultan Amai Gorontalo, Indonesia.
} 
intrinsik harus mendasarkan kerangka pikirannya pada dua kerangka utama dalam analisis fundamental yaitu Earning Per Share dan Price Earning Ratio (Tandelilin, 2001)

PT Mayora Indah Tbk merupakan perusahaan yang mempunyai kampiun ekspor produk-produk konsumsi dengan tujuan ekspor ke sekitar 80 negara. Garfik berikut ini memberikan gambaran rata-rata harga saham pada PT Mayora Indah Tbk:

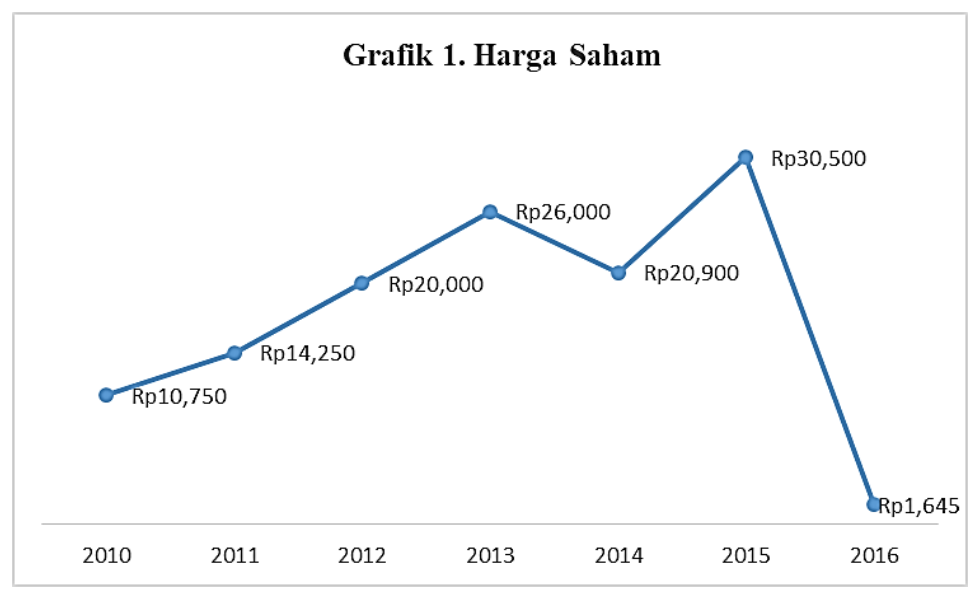

Harga saham PT Mayora Indah Tbk mengalami fluktuasi dari tahun 2010 sampai dengan tahun 2016. Harga saham yang berfluktuasi disebabkan oleh adanya kekuatan permintaan dan penawaran dari investor dalam keyakinannya berinvestasi. Pergerakan harga saham tersebut belum menunjukan nilai yang sebenarnya (nilai intrinsik) dari sebuah saham sehingga belum dapat dikategorikan rendah (undervalued), wajar (fairly priced) atau terlalu tinggi (overvalued).

Informasi tersebut sangat penting bagi para investordalam memberikan penilaian dan pertimbangan untuk menjual, membeli, atau menahan sejumlah saham pada PT Mayora Indah Tbk karena para investor terlebih dahulu akan membandingkan nilai intrinsik dengan harga pasar saham perusahaan, sebelum para investor mengambil keputusan investasi terhadap saham yang akan di beli, dijual atau menahan saham. Untuk mengetahui nilai instrinsik saham dapat dihitung dengan menggunakan Price Earning Ratio.

\section{Tinjauan Teoritis}

\section{a) Pasar Modal}

Pasar modal (capital market) merupakan tempat diperjualbelikan berbagai instrumen keuangan jangka panjang seperti utang, ekuitas (saham), instrumen derivatif, maupun instrumen lainnya (Darmajdi dan Fakhrudin, 2012:1). Pasar modal juga bisa diartikan sebagai pasar untuk memperjualbelikan sekuritas yang umumnya memiliki umur lebih dari satu tahun 
(Tandelilin, 2001:13). Dan pengertian pasar modal yang lebih spesifik adalah kegiatan yang bersangkutan dengan penawaran umum dan perdagangan efek, perusahaan publik yang berkaitan dengan efek yang diterbitkannya, serta lembaga dan profesi yang berkaitan dengan efek. Pasar modal adalah pertemuan antara pihak yang memiliki kelebihan dana dengan pihak yang membutuhkan dana dengan cara memperjualbelikan sekuritas (Undang-Undang Pasar ModalNo. 8 Tahun 1995).

\section{b) Saham}

Saham adalah surat berharga yang dikeluarkan oleh sebuah perusahaan yang berbentuk Perseroan Terbatas (PT) atau yang biasa disebut emitmen. Saham menyatakan bahwa pemilik saham tersebut adalah juga pemilik sebagian dari perusahaan tersebut (Sunariyah, 2006 :126-127). Sedangkan menurut Riyanto (2001:240) Saham adalah tanda bukti pengembalian bagian atau peserta dalam perseroan terbatas, bagi yang bersangkutan, yang diterima dari hasil penjualan sahamnya akan tetapi tertanam di dalam perusahaan tersebut selama hidupnya, meskipun bagi pemegang saham sendir bukanlah merupakan peranan permanen, karena setiap waktu pemegang saham dapat menjual sahamnya.

Terdapat beberapa nilai dalam suatu saham diantaranya Nilai buku (book valued), Nilai Pasar (market value) dan Nilai Interinsik. Nilai buku perlembar saham menunjukkan aktiva bersih (net assets) yang dimiliki oleh pemegang saham dengan memiliki satu lembar saham. Karena aktiva bersih sama dengan total ekuitas pemegang saham, maka nilai buku (book valued)perlembar saham adalah total ekuitas dibagi dengan jumlah saham yang beredar.Nilai pasar(market value) merupakan harga saham yang terjadi di pasar bursa pada saat tertentu yang ditentukan oleh pelaku pasar. Dengan kata lain nilai pasar ini ditentukan oleh permintaan dan penawaran saham yang bersangkutan di pasar bursa. Dan Nilai intrinsik disebut juga dengan nilai fundamental, merupakan nilai sebenarnya dari saham. Dua macam analisis yang banyak digunakan dalam menentukan nilai intrinsik dari saham adalah analisis teknikal dan analisis fundamental.(Jogiyanto,2003:79-107).

Investor perlu mengetahui ketiga jenis nilai saham tersebut untuk mengetahui informasi yang sedang berkembang, sehingga dapat menentukan kebijakan investasi yang tepat. Seorang investor membandingkan antara nilai intrinsik saham tersebut dengan nilai pasar. Jika nilai pasar yang bersangkutan lebih dari nilai intrinsiknya, berarti harga saham tersebut termasuk mahal (overvalued). Maka seorang investor bisa mengambil keputusan untuk menjual saham tersebut. Sebaliknya, jika nilai pasar lebih rendah daripada nilai 
intrinsik saham, maka harga saham di pasar tergolong murah (undervalued), maka seorang investor bisa membeli saham tersebut (Sunariyah, 2006:178).Menurut Darmadji dan Fakhrudin (2012:6) ada beberapa jenis saham yaitu:

- Ditinjau dari segi kemampuan dalam hak tagih atau klaim, maka saham terbagi atas:

1) Saham biasa (common stock), yaitu merupakan saham yang menempatkan pemiliknya paling junior terhadap pembagian saham deviden, dan hak atas harta kekayaan perusahaan apabila perusahaan tersebut dilikuidasi.

2) saham preferen (preferred stock), merupakan saham yang memiliki karakteristik gabungan antara obligasi dan saham biasa, karena bisa menghasilkan pendapat tetap (seperti bunga obligasi), tetapi juga bisa tidak mendatangkan hasil seperti ini yang dikehendaki oleh investor.

- Dilihat dari cara peralihannya, saham dibedakan menjadi:

1) Saham atas unjuk (bearer stock), artinya pada saham tersebut tidak tertulis nama pemiliknya, agar mudah dipindahtangankan dari satu investor ke investor lain.

2) Saham atas nama (registered stock), merupakan saham yang ditulis dengan jelas siapa nama pemiliknya, di mana cara peralihannya harus melalui prosedur tertentu.

- Ditinjau dari kinerja perdagangannya, maka saham dapat dikategorikan menjadi:

1) Saham unggulan (blue-chip stock), yaitu saham biasa dari suatu perusahaan yang memiliki reputasi tinggi, sebagai leader di industry sejenis, memiliki pendapatan yang stabil dan konsisten dalam membayar deviden.

2) Saham pendapatan (income stock), yaitu saham biasa dari suatu entimen yang memiliki kemampuan membayar deviden lebih tinggi dari ratarata deviden yang dibayarkan pada tahun sebelumnya.

3) Saham pertumbuhan (growth stock-well known), yaitu saham-saham dari emiten yang memiliki pertumbuhan pendapatan yang tinggi, sebagai leader di industri sejenis yang mempunyai reputasi tinggi. Selain itu terdapat juga growth stock lesser known, yaitu saham dari emiten yang tidak sebagai leader dalam industri namun memiliki ciri growth stock.

4) Saham spekulatif (speculative stocks), yaitu saham suatu perusahaan yang tidak bisa secara konsisten memperoleh penghasilan dari tahun ke tahun, akan tetapi memungkinkan penghasilan yang tinggi di masa mendatang, meskipun belum pasti. 
5) Saham skikal (counter cyclical stocks), yaitu saham yang tidak terpengaruh oleh kondisi ekonomi makro maupun situasi bisnis secara umum

\section{c) Analisis Saham}

Dalam konteks teori untuk melakukan analisis dan memilih saham terdapatdua pendekatan dasar yakni:

\section{Analisis Teknikal}

Analisis teknikal adalah teknik untuk memprediksiarah pergerakan harga saham dan indikator pasar saham lainnya berdasarkanpada data pasar historis seperti informasi harga saham dan volume (Tandelilin, 2010:392). Sedangkan menurut Rahardjo (2006) mendefinisikan, bahwa Analisis teknikal merupakan suatu metodologi peramalan fluktuasi harga saham yang datanya diambil dari data perdagangan saham yang terjadi di pasar saham atau bursa efek. Jenis datanya sendiri bisa berbentuk informasi harga saham, jumlah volume \& nilai transaksi perdagangan, harga tertinggi \& terendah pada perdagangan setiap hari, atau berbagai informasi lain yang terkait dengan transaksi saham yang terwujud dalam bentuk tren harga saham; bisa dalam bentuk grafik atau sejenisnya. Dan Sunariyah (2006) menjelaskan bahwa analisis teknikal (technical analysis) merupakan suatu teknik analisis yang menggunakan data atau catatan mengenai pasar itu sendiri untuk berusaha mengakses permintaan serta penawaran suatu saham tertentu atau pasar secara keseluruhan. Pendekatan analisis ini sendiri menggunakan data pasar yang dipublikasikan, seperti harga saham, volume perdagangan, indeks harga saham gabungan dan individu, serta faktor-faktor lain yang bersifat teknis.

Analisis Fundamental

Analisis fundamental merupakan salah satu cara untuk melakukan penilaian saham dengan mempelajari atau mengamati berbagai indikator yang terkait dengan kondisi makro ekonomi dan kondisi industri suatu perusahaan hingga berbagai indikator keuangan dan manajemen perusahaan(Darmadji dan Fakhrudin, 2012:149). Dan Menurut Halim (2005) Analisis Fundamental merupakan suatu analisis yang membandingkan antara nilai intrinsik suatu saham dengan harga pasarnya yang mana digunakan dalam menentukan apakah harga pasar tersebut sudah mencerminkan nilai intrinsiknya atau belum.

Untuk melakukan analisis nilai intrinsic seorang investor atau peneliti harus mendasarkan kerangka pikirannya pada dua kerangka utama dalam analisis fundamental yaitu : EPS (Earning Per Share) dan PER (Price Earning Ratio) (Tandelilin, 2001). Terdapat tiga 
alasan yang mendasar penggunaan dua komponen tersebut. Pertama karena pada dasarnya kedua komponen tersebut bisa dipakai untuk mengestimasi nilai intrinsik suatu saham (yang mana merupakan tujuan analisis fundamental). Dalam kaitan tersebut nilai intrinsik suatu saham 4 bisa dihitung dengan mengalikan kedua komponen tersebut. Jika dibandingkan harga pasar saham yang bersangkutan akan berguna untuk keputusan menjual atau membeli saham. Kedua, dividen yang di bayarkan perusahaan pada dasarnya di bayarkan dari earning. Ketiga, adanya hubungan antara perubahan earning dengan harga saham. Beberapa peneliti empiris telah membuktikan adanya hubungan tersebut (Elton dan Gruber, 1995).

\section{d) Pendekatan Price Earning Ratio}

Pendekatan ini yang populer untuk mengestimasi nilai intrinsik saham, investor akan menghitung berapa kali nilai earning yang tercermin dalam harga suatu saham. Price Earning Ratio menggambarkan rasio atau perbandingan antara harga saham terhadap earning perusahaan. Rasio ini menunjukkan berapa besar investor menilai harga dari saham terhadap kelipatan dari earnings(Jogiyanto, 2003:205). Price Earning Ratio juga memberikan informasi berapa rupiah harga yang harus dibayar untuk memperoleh setiap Rp 1,00 earning perusahaan, semakin tinggi nilai Price Earning Ratio maka semakin kecil keuntungan yang didapat untuk setiap lembar saham dan semakin rendah nilai Price Earning Ratio maka semakin besar keuntungan yang didapat setiap lembar saham. Penilaian saham dengan pendekatan Price Earning Ratio adalah untuk membuat analisis harga saham dengan memperhatikan kinerja keuangan yang dianggap mempengaruhi nilai saham (Tandelilin, 2001:191).

Dengan menghitung Rasio Price Earning Ratio, kita dapat mengetahui seberapa besar harga yang ingin dibayar oleh pasar terhadap pendapatan atau laba suatu perusahaan. Rasio Price Earning Rationya yang lebih tinggi menunjukan bahwa pasar bersedia membayar lebih terhadap pendapatan atau laba suatu perusahaan, serta memiliki harapan yang tinggi terhadap masa depan perusahaan tersebut sehingga bersedia untuk menghargainya dengan harga yang lebih tinggi. Di sisi lain, Rasio Harga Terhadap Pendapatan (Price Earning Rasio) yang lebih rendah mengindikasikan bahwa pasar tidak memiliki kepercayaan yang cukup terhadap masa depan saham perusahaan yang bersangkutan.

\section{e) Keputusan Investasi}

Investasi adalah penundaan konsumsi sekarang untuk dimasukkan ke aktiva produktif selama periode waktu tertentu(Jogiyanto, 2010:5). Investasi adalah komitmen atas sejumlah 
dana atau sumber daya lainnya yang dilakukan pada saat ini dengan tujuan memperoleh sejumlah keuntungan di masa datang (Tandelilin,2001:3).Investasi adalah penanaman modal untuk satu atau lebih aktiva yang dimiliki dan biasanya berjangka waktu lama dengan harapan mendapatkan keuntungan dimasa yang akan datang. Keputusan penanaman modal tersebut dapat dilakukan oleh individu atau suatu entitas yang mempunyai kelebihan dana (Sunariyah,2006:4).

Pengambilan keputusan investasi baru dapat dilakukan oleh investor setelah melakukan penilaianterhadap harga saham. Menurut Husnan (2003:288) analisis saham bertujuan untuk menaksir nilaiintrinsik suatu saham, dan kemudian dibandingkan dengan harga pasar saat ini saham tersebut. Nilaiintrinsik (NI) menunjukkan present value arus kas yang diharapkan dari saham tersebut. Dalam penilaian nilai intrinsik saham digunakan pedoman berikut :

- Apabila NI > harga pasar saat ini, maka saham tersebut dinilai undervalued (harganya terlalurendah), dan karenanya seharusnya dibeli atau ditahan apabila saham tersebut telah dimiliki.

- Apabila NI < harga pasar saat ini, maka saham tersebut dinilai overvalued (harganya terlalu mahal), dan karenanya harus dijual.

- Apabila NI= harga pasar saat ini, maka saham tersebut dinilai wajar harganya dan berada dalamkondisi keseimbangan. Keputusan investasi yang dapat diambil adalah mempertahankan saham tersebut tidak menjual atau tidak membeli saham tersebut sampai kondisi yang menguntungkan bagi investor.

\section{Metode Penelitian}

Penelitian ini menggunakan metode kuantitatif dengan pendekatan deskriptif dimana peneliti berusaha untuk memahami analisis tentang penetapan nilai intrinsik saham menggunakan metode Price Earning Ratio. Jenis data yang digunaka dalam penelitian ini adalah Data kauntitatif dimana data yang berbentuk angka misalnya harga saham, besarnya pendapatan dan jumlah saham, Data diperoleh/dikumpulkan dari http://www.mayoraindah.co.id/ dan data dikumpulkan dari tahun 2010 sampai 2016 hal ini biasa disebut dengan time series data yaitu data yang dikumpulkan dari waktu ke waktu untuk melihat perkembangan suatu kejadian/kegiatan selama periode tersebut. Data yang diperoleh dianalisis dengan cara: 
a) Menghitung Price Earning Ratio dengan Rumus:

$$
\left.\mathrm{Po}=\frac{\mathrm{D}}{\mathrm{k}-\mathrm{g}} 6: 206\right)
$$

\section{Keterangan:}

Po $=$ Nilai intrinsik saham dengan model pertumbuhan nol

$\mathrm{D}=$ Dividen yang akan diterima dalam jumlah konstan selama periode pembayaran dividen di masa datang

$\mathrm{g}=$ Tingkat pertumbuhan dividen

$\mathrm{k}=$ Tingkat return yang disyaratkan

Dividen yang akan diterima dalam jumlah konstan selama periode pembayaran dividen di masa datang dihitung digunakan persamaan :

$$
\mathrm{D}=\mathrm{D}_{0}(1+\mathrm{g}) \quad(\text { Tambunan 2007:230) }
$$

Nilai Tingkat pertumbuhandividen (g) dihitung dengan persamaan:

$$
\mathrm{g}=\mathrm{ROE} \mathrm{x} \text { retention rate (tingkat laba ditahan) }
$$

Dimana:

$R O E=$ Laba bersih atas modal sendiri

Retention Rate $=1$ - Dividen payout ratio

Dividen payout ratio $=\frac{\text { dividen per share }}{\text { Earning per share }}$ (Tandelilin, 2010:376)

DPS = Dividen yang dibagikan per lembar saham

EPS = Earning yang didapatkan per lembar saham

Tingkat return yang disyaratkan ( $\mathrm{k}$ ) dihitung dengan persamaan:

$$
\mathrm{k}=\frac{\mathrm{D}}{\mathrm{P}_{0}}+\mathrm{g}
$$

(Brigham dan Houston 2001:369)

Dimana :

$\mathrm{k}=$ Tingkat return yang disyaratkan (required rate of return)

$\mathrm{D}=$ Dividen terakhir 
Volume. 13, Nomor 2, Desember 2017

Hataman. 01-17
Analisis Metode Price Earning Ratio Dalam Penetapan Nilai Intrinsik Saham

$$
\begin{aligned}
& \mathrm{P}_{0}=\text { Harga pasar saat ini } \\
& \mathrm{g} \quad=\text { Tingkat pertumbuhan dividen }
\end{aligned}
$$

b) Melakukan Analisis perhitungan penetapan nilai intrinsik saham dengan menggunakan metode Price Earning Ratiodimana:

Tabel 1. Penetapan Nilai Intrinsik

\begin{tabular}{|l|l|}
\hline \multicolumn{1}{|c|}{ Keterangan } & KondisiSaham \\
\hline HargaIntrinsik>Hargapasarsaham & Undervalued \\
\hline HargaIntrinsik<Hargapasarsaham & Overvalued \\
\hline HargaIntrinsik = Hargapasarsaham & Corectly Valued \\
\hline
\end{tabular}

Sumber : Husnan (2003:288)

\section{Hasil Penelitian dan Pembahasan}

Berikut ini adalah data yang akan digunakan untuk mendapatkan nilai Price Earning Ratioyang terdiri dari Harga per lembar saham, Dividen, Earning After Tax dan Jumlah

\begin{tabular}{|c|c|c|c|c|}
\hline Tahun & $\begin{array}{c}\text { Hargaperlembarsaha } \\
\mathrm{m}\end{array}$ & Dividen & $\begin{array}{c}\text { EAT } \\
\text { (Earning After Tax) }\end{array}$ & $\begin{array}{l}\text { Jumlahsaham } \\
\text { yang beredar }\end{array}$ \\
\hline 2010 & Rp 10.750 & $\begin{array}{l}\mathrm{Rp} \\
76.658 .400 .000\end{array}$ & $\begin{array}{l}\mathrm{Rp} \\
499.655 .171 .512\end{array}$ & $\begin{array}{c}\mathrm{Rp} \\
766.584 .000\end{array}$ \\
\hline 2011 & Rp 14.250 & $\begin{array}{l}\mathrm{Rp} \\
99.655 .920 .000\end{array}$ & $\begin{array}{l}\mathrm{Rp} \\
483.486 .152 .677\end{array}$ & $\begin{array}{c}\mathrm{Rp} \\
766.584 .000\end{array}$ \\
\hline 2012 & Rp 20.000 & $\begin{array}{l}\mathrm{Rp} \\
99.655 .920 .000\end{array}$ & $\begin{array}{l}\mathrm{Rp} \\
744.428 .404 .309\end{array}$ & $\begin{array}{c}\mathrm{Rp} \\
766.584 .000\end{array}$ \\
\hline 2013 & $\mathrm{Rp} 26.000$ & $\begin{array}{l}\mathrm{Rp} \\
176.314 .320 .000\end{array}$ & $\begin{array}{l}\mathrm{Rp} \\
1.013 .558 .238 .779\end{array}$ & $\begin{array}{l}\mathrm{Rp} \\
894.347 .989\end{array}$ \\
\hline 2014 & Rp 20.900 & $\begin{array}{l}\mathrm{Rp} \\
205.700 .037 .470\end{array}$ & $\begin{array}{l}\mathrm{Rp} \\
409.824 .768 .594\end{array}$ & $\begin{array}{c}\mathrm{Rp} \\
894.347 .989\end{array}$ \\
\hline 2015 & Rp 30.500 & $\begin{array}{l}\mathrm{Rp} \\
143.095 .678 .240\end{array}$ & $\begin{array}{l}\mathrm{Rp} \\
1.250 .233 .128 .560\end{array}$ & $\begin{array}{c}\mathrm{Rp} \\
894.347 .989 \\
\end{array}$ \\
\hline 2016 & $\mathrm{Rp} \quad 1.645$ & $\begin{array}{l}\mathrm{Rp} \\
268.304 .396 .700\end{array}$ & $\begin{array}{l}\mathrm{Rp} \\
1.388 .676 .127 .665\end{array}$ & $\begin{array}{c}\mathrm{Rp} \\
894.347 .989\end{array}$ \\
\hline
\end{tabular}
saham yang beredar dari tahun 2010 - 2016:

Sedangkan hasil perhitungan nilai intrinsik saham dengan model pertumbuhan nol PT Mayora Indah Tbk Tahun 2010-2016 adalah:

\begin{tabular}{|c|cc|cc|c|c|}
\hline Tahun & \multicolumn{2}{|c|}{ D } & \multicolumn{2}{|c|}{ k } & g & NilaiIntrinsik \\
\hline 2010 & $\mathrm{Rp}$ & 76.658 .400 .000 & $\mathrm{Rp}$ & $7.131 .035,28$ & 21,33 & $\mathrm{Rp} 10.750$ \\
\hline 2011 & $\mathrm{Rp}$ & 99.655 .920 .000 & $\mathrm{Rp}$ & $6.993 .413,64$ & 15,75 & $\mathrm{Rp} 14.250$ \\
\hline
\end{tabular}




\begin{tabular}{|l|l|lr|c|c|}
2012 & $\mathrm{Rp} 99.655 .920 .000$ & $\mathrm{Rp} 4.982 .817,11$ & 21,11 & $\mathrm{Rp} 20.000$ \\
\hline 2013 & $\mathrm{Rp} \mathrm{176.314.320.000}$ & $\mathrm{Rp} 6.781 .341,60$ & 21,60 & $\mathrm{Rp} 26.000$ \\
\hline 2014 & $\mathrm{Rp} 205.700 .037 .470$ & $\mathrm{Rp} 9.842 .112,06$ & 5,00 & $\mathrm{Rp} 20.900$ \\
\hline 2015 & $\mathrm{Rp} \mathrm{143.095.678.240}$ & $\mathrm{Rp} 4.691 .683,00$ & 21,42 & $\mathrm{Rp} 30.500$ \\
\hline 2016 & $\mathrm{Rp} 268.304 .396 .700$ & $\mathrm{Rp} 163.102 .994,67$ & 17,95 & $\mathrm{Rp} 1.645$ \\
\hline
\end{tabular}

Dari data diatas menunjukkan bahwa pada tahun 2010 nilai intrinsik PT Mayora Indah

Tbk sebesar $\mathrm{Rp}$ 10.750, hal ini dipengaruhi tingkat return yang disyaratkan $(\mathrm{k})$ menurun karena nilai dividen yang meningkat, harga saham di pasar saham yang meningkat, dan nilai tingkat pertumbuhan dividen yang menurun. Sedangkantingkat pertumbuhan dividen (g) yang menurun disebabkan oleh nilai ROE (return on equity) yang meningkat dan jumlah retention rate (tingkat laba ditahan) yang menurun. Pada tahun 2011 nilai intrinsik PT Mayora Indah Tbk meningkat menjadi sebesar Rp 14.250, hal ini dipengaruhi oleh dividen yang meningkat karena laba yang meningkat dan jumlah beban-beban yang dibayarkan hanya sedikit. Tingkat return yang disyaratkan $(\mathrm{k})$ menurun disebabkan oleh nilai dividen yang meningkat, harga saham di pasar saham meningkat, dan nilai tingkat pertumbuhan dividen yang menurun. Dan tingkat pertumbuhan dividen (g) yang menurun disebabkan oleh nilai ROE (return on equity) yang meningkat dan jumlah retention rate (tingkat laba ditahan) juga menurun.

Pada tahun 2012 nilai intrinsik PT Mayora Indah Tbk meningkat menjadi sebesar Rp20.000, hal ini dipengaruhi oleh tingkat return yang disyaratkan (k) menurun karena nilai dividen yang meningkat, harga saham di pasar saham yang meningkat, dan nilai tingkat pertumbuhan dividen yang menurun. Sedangkan tingkat pertumbuhan dividen (g) yang meningkat disebabkan oleh nilai ROE (return on equity) yang meningkat dan jumlah retention rate (tingkat laba ditahan) yang meningkat pula.Pada tahun 2013 nilai intrinsik PT Mayora Indah Tbk meningkat menjadi sebesar Rp 26.000, hal ini dipengaruhi oleh dividen yang meningkat karena laba yang meningkat dan jumlah beban-beban yang dibayarkan hanya sedikit. Nilai tingkat return yang disyaratkan (k) meningkat disebabkan oleh nilai dividen yang meningkat, harga saham di pasar saham yang meningkat, dan nilai tingkat pertumbuhan dividen yang meningkat. Dan nilai tingkat pertumbuhan dividen (g) yang meningkat disebabkan oleh nilai ROE (return on equity) yang meningkat dan jumlah retention rate (tingkat laba ditahan) yang menurun.Pada tahun 2014 nilai intrinsik PT Mayora Indah Tbk menurun menjadi sebesar Rp 20.900, hal ini dipengaruhi oleh dividen yang meningkat karena laba yang meningkat dan jumlah beban-beban yang dibayarkan hanya sedikit. Nilai tingkat return yang disyaratkan $(\mathrm{k})$ meningkat disebabkan oleh nilai dividen yang meningkat, harga 
saham di pasar saham yang meningkat, dan nilai tingkat pertumbuhan dividen yang menurun. Dan nilai tingkat pertumbuhan dividen (g) yang menurun disebabkan oleh nilai ROE (return on equity) yang menurun dan jumlah retention rate (tingkat laba ditahan) yang menurun.

Pada tahun 2015 nilai intrinsik PT Mayora Indah Tbk meningkat menjadi sebesar Rp 30.500, hal ini dipengaruhi oleh dividen yang menurun karena laba yang menurun dan jumlah beban-beban yang dibayarkan terlalu banyak. Nilai tingkat return yang disyaratkan (k) menurun disebabkan oleh nilai dividen yang menurun, harga saham di pasar saham yang meningkat, dan nilai tingkat pertumbuhan dividen yang meningkat. Dan nilai tingkat pertumbuhan dividen (g) yang meningkat disebabkan oleh nilai ROE (return on equity) yang meningkat dan jumlah retention rate (tingkat laba ditahan) yang meningkat.Pada tahun 2016 nilai intrinsik PT Mayora Indah Tbk menurun menjadi sebesar Rp 1.645, hal ini dipengaruhi oleh dividen yang meningkat disebabkan oleh laba yang meningkat dan jumlah beban-beban yang dibayarkan hanya sedikit. Nilai tingkat return yang disyaratkan (k) meningkat disebabkan oleh nilai dividen yang meningkat, harga saham di pasar saham yang menurun, dan nilai tingkat pertumbuhan dividen yang menurun. Nilai Tingkat pertumbuhan dividen (g) yang menurun disebabkan oleh nilai ROE (return on equity) yang menurun dan jumlah retention rate (tingkat laba ditahan) yang menurun.Nilai intrinsik saham dengan model pertumbuhan nol pada PT Mayora Indah Tbk Tahun 2010-2016 menunjukan hasil yang sama dengan harga pasar sahamnya saat ini, yang berarti hasil dari nilai intrinsik ini sama dengan kondisi saham yaitu correctly valueddimana terjadi keseimbangan karena saham tersebut mempunyai nilai yang wajar yang menunjukan harga saham yang terjadi di pasar saham dengan nilai yang sebenarnya yang harus terjadi di pasar saham.

Investor dan analisis sekuritas menghubungkan antara nilai intrinsik saham dan nilai pasar saham saat ini untuk menilai apakah harga saham yang ditawarkan emiten sesuai dengan harga yang wajar. Jika nilai intrinsik lebih besar dari pada nilai pasar saham, maka harga saham tersebut dinilai undervalued. Dalam kondisi ini, sebaiknya dilakukan pembelian atau ditahan apabila saham tersebut telah dimiliki. Jika nilai intrinsik lebih kecil dari pada nilai pasar saham, maka harga saham tersebut dinilai overvalued. Sehingga sebaiknya tidak dilakukan pembelian atau dijual apabila saham tersebut telah dimiliki. Jika nilai intrinsik sama dengan nilai pasar saham, maka saham tersebut dinilai correctly valued dan biasanya transaksi cenderung tidak ada untuk saham tersebut.Sesuai dengan analisis di atas Penetapan Nilai intrinsik saham PT Mayora Indah Tbk sudah merupakan nilai yang wajar/nilai 
sebenarnya (yang seharusnya) dari harga saham di pasar saham. Hal ini sesuai dengan asumsi yang menyatakan bahwa nilai Intrinsik (intrinsic value) atau fundamental value merupakan nilai seharusnya sebuah saham.

\section{Kesimpulan}

Dari hasil penelitian untuk penetapan nilai intrinsik saham PT Mayora Indah Tbk dengan menggunakan Metode Price Earning Ratio dapat diketahui bahwa nilai intrinsik sahamnya sudah tepat dan telah sama dengan harga pasar sahamnya sebab berada pada posisi Correctly Valued yaitu nilai intrinsik saham sama dengan atau seimbang dengan harga pasar saham. Dimana nilai intrinsiknya sudah merupakan nilai yang wajar atau nilai yang sebenarnya (yang seharusnya) terjadi di pasar saham.

\section{Daftar Pustaka}

Brigham, Eugene F., dan Joul F. Houston. 2001. Manajemen Keuangan. Edisi Bahasa Indonesia. Erlangga: Jakarta.

Brigham, Eugene dan Houston. 2006, Fundamental of Financial Management : Dasar-Dasar Manajemen Keuangan. Edisi 10. Salemba Empat: Jakarta

Darmadji, Tjiptono, dan Fakhrudin. 2012. Pasar Modal DiIndonesia. Edisi Ketiga. Salemba Empat: Jakarta

Elton, Edwin J. and Martin J. Gruber. 1995. Modern Portfolio Theory andInvestment Analysis. Toronto: John Wiley \& Sons.

Halim, Abdul. 2005. Analisis Investasi. Edisi Kedua. Salemba Empat, Alfabeta: Jakarta

Husnan, Suad. 2003. Dasar-Dasar Teori Portofolio dan Analisis Sekuritas. AMP YPKN: Yogyakarta.

Indonesia, Undang - Undang Pasar Modal. Undang - Undang No. 8 Tahun 1985 LN No.64 Tahun 1995, TLN No. 3608

Jogiyanto, Hartono. 2003. Teori Portofollio dan Analisis Investasi, Edisi kelima.BPFE: Yogyakarta

Jogiyanto Hartono, 2016. Teori Portofolio Dan Analisis Investasi, Edisi Kesepuluh. BPFE: Yogyakarta.

Rahardjo, Sapto. 2006. Kiat Membangun Aset Kekayaan (Panduan Investasi Saham). PT Elex Media Komputindo: Jakarta

Riyanto, Bambang. 2001. Dasar - Dasar Pembelanjaan Perusahaan, Edisi Keempat Cetakan Ketujuh, BPFE: Yogyakarta.

Sunariyah. 2006. Pengantar Pengetahuan Pasar Modal. UPP STIM YKPN: Yogyakarta

Sulistyastuti, Dyah Ratih. 2002. Saham dan Obligasi. Edisi Pertama, Cetakan Petama. UAJY: Yogyakarta 
Volume. 13, Nomor 2, Desember 2017

Hataman. 01-17
Anatisis Metode Price Earning Ratio Dalam Penetapan Nitai Intrinsik Saham

Tandelilin, Eduardus. 2001. Analisis Investasi dan Portofolio. BPFE: Yogyakarta

Tandelilin, Eduardus. 2010. Portofolio dan Investasi dan Aplikasi. Edisi pertama. Kanisius: Yogyakarta

Tambunan, Andy P. 2007. Menilai harga wajar saham (stock valuation). PT Elex Media Komputindo: Jakarta

http://www.mayoraindah.co.id/ 